\title{
Impact of Implementing a Leadership Development Training Program for Staff Nurses on Structural Empowerment, Leadership Self-Efficacy, and Clinical Leadership Practices
}

\author{
Rabab Saleh Shaheen, Assistant lecture
}

Nursing Administration, Faculty of Nursing, Alexandria University

Zeinab Mohamed Nabawy, Professor

Nursing Administration, Faculty of Nursing, Alexandria University

\author{
Nadia Hassan Ali Awad, Assistant professor \\ Nursing Administration, Faculty of Nursing, Alexandria University
}

\begin{abstract}
Background: The uncertainty in the health care organizations, particularly in nursing, makes the new millennium an important time for nurses to develop leadership skills. One of the greatest challenges faced in the nursing profession is developing future nurse leader. Nurses must have leadership to move forward in harmony with changes in society and in health care. The leadership development program is a useful way for "unfreezing" views, ideas and opinions about leadership competence and, more importantly, for showing how the bedside nurses saw themselves as leaders; be empowered, have confidence in his/her abilities as a future leader and employ leadership practices. Objective: To determine the impact of implementing a leadership development training program for staff nurses on structural empowerment, leadership self-efficacy, and clinical leadership practices. Settings: This study was conducted in Inpatient Surgical Care Units at Alexandria Main University Hospital ( $\mathrm{N}=15)$ Subjects: Nurses who are working in surgical units at morning and afternoon shift was selected randomly by simple random sample $(\mathrm{N}=40)$ were included in the study. Tools: Three tools were used in this study. The first tool was Conditions of Work Effectiveness Questionnaire-II (CWEQ-II) to measure structural empowerment. The second tool was Clinical Nurse Leadership Self-Efficacy Scale (CNLSE)) to assess the nurse's confidence in performance of each of the 9 practice competencies of the clinical nurse leader. The third tool was Clinical Leadership Observation Scale to assess clinical leadership of staff nurses aligning with Kouzes and Posner (2007) model. In addition, demographic data sheet was developed by the researcher; and included questions related to gender, age, educational qualification, working unit, years of units and nursing experience Results: findings of the present study revealed that there was a highly significant improvement of overall structural empowerment and its dimensions, leadership self-efficacy and its dimensions as well as clinical leadership practices and its dimensions in the three phases of evaluation (before, immediately after and after 2 month of program implementation). The program also had moderate effect on structural empowerment and leadership self-efficacy and large effect on both clinical leadership practices and leadership knowledge. Conclusion: The study concluded that there was a highly positive significant correlation between leadership self-efficacy and structural empowerment and between clinical leadership practices and structural empowerment and leadership self-efficacy immediately after program implementation. Recommendations: Organization need to identify the essential leadership competencies required for bedside nursing staff and develop programs to enhance these competencies and should devote a minimum of two weeks per year to leadership training and education.
\end{abstract}

Keywords: Leader, Clinical, Nurse, Develop, Empower, Self-efficacy

\section{Introduction}

Nurse leaders are also vital in the workplace to elicit input from others and to formulate a vision for the preferred future (Evans, 2016). 
Therefore, Nurses at the bedside should be viewed as challengers to the traditional assumptions of leadership for preparing new generation of future leaders that is the focuses of Egypt vision 2030 (Chavez \& Yoder, 2015).

Kouzes and Posner (2007) developed a leadership model which purportedly measures five key leadership practices each of them include two strategies consistent with transformational leadership style, including behaviors associated with; modeling the way that involves setting the example by behaving in ways that are consistent with shared values; achieving small "wins" that promote consistent progress and build commitment. Inspiring a shared vision that includes envisioning an uplifting and ennobling future; enlisting others in a common vision by appealing to their values, interests, hopes and dreams. Challenging the process that involves searching out challenging opportunities to change, grow, innovate, and improve; experimenting taking risks, and learning from the accompanying mistakes. Enabling others to act that focuses on fostering collaboration by promoting cooperative goals and building trust; strengthening people by giving power away, providing choice, and developing competence, assigning critical tasks, and offering visible support. Encouraging the heart means recognizing individual contributions to the success of every project; celebrating team accomplishments regularly.

A leadership development refers to the capability that is aim to achieving organizational targets and further influences all the activities done. It determines the level of motivations and empowerment of the staff nurses (Tjosvold \& Wong, 2000)

Empowerment defined by Clark, (2011) as "the process of promoting and enhancing nurses' ability to make appropriate decision to meet organizational expectation, and to solve problems in the work setting through interaction and effective communication with supervisor and colleagues". Empowerment classified into two types, structure empowerment and psychological empowerment (Carlson-Catalano, 1992). Echebiri et al. (2020) defined structural empowerment as "the organization's ability to offer access to information, resources, support and opportunity in the work environment". Workplaces that are empowered are linked to positive organizational environments, behaviors and attitudes, and these characteristics are linked to increase retention of nurses, job satisfaction, autonomy, dedication to their organizations and self-efficacy (Kanter, 1993; Laschinger et al., 2007).

The significant influence of self-efficacy on individual performance has been well established, and the positive results have been extended to the leadership area (Paglis, 2010). Paglis and Green (2002) defined Leadership Self-Efficacy (LSE) as “a person's judgment that he/s can successfully exert leadership by setting a direction for the work group, building relationships with followers in order to gain commitment to goals, and working with them to overcome obstacles to change". Gilmartin \& Nokes (2015) developed a Clinical Nurse Leadership self-efficacy Scale (CNLSES), a state-specific self-efficacy scale that is focuses on assessing nurses' perceptions of their ability to function effectively as clinical nurse leader.

Leadership self-efficacy is a psychological resource that helps health care organizations struggle to adapt to ever-accelerating rates of change both internally with the external environment in which they are embedded. Such change challenges include the knowledge, skills and abilities of leaders, and perhaps even more important, the selfconceptualizations of their leadership capabilities as a clinical leader (Hannah et al., 2008).

Patrick et al., (2011) defined clinical leadership as "staff nurse behavior's that provide direction and support to clients and the health care team in the delivery of patient care". These behaviors reduce the likelihood of adverse events arising from changes in patient conditions by early 
identification and timely responses to lifethreatening complications that may develop.

\section{Aims of the Study}

This study aims to determine the impact of implementing a leadership development training program for staff nurses on their structural empowerment, leadership self-efficacy, and clinical leadership practices.

\section{Research hypotheses}

H1: Staff nurses undergoing a leadership development training program exhibit higher level of structure empowerment than before.

H2: Staff nurses undergoing a Leadership development training program exhibit higher level of leadership self-efficacy than before.

H3: Staff nurses undergoing a Leadership development training program exhibit higher level of clinical leadership practices than before

\section{Materials and Method}

\section{Materials}

\section{Design:}

A quasi-experimental research (one group pre-test, post-test) design

\section{Settings:}

This study was conducted in all Inpatient Surgical Care Units at Alexandria Main University Hospital ( $\mathrm{N}=15)$ namely; cardio thorax, neurology, head and neck, vascular, hepatic, neurosurgery, plastic, otorhinolaryngology, GIT, ophthalmology, colon and rectum, oncology, children surgery, urology (male and female)and children urology.

\section{Subjects:}

Total number of nurses who are working in surgical units at morning and afternoon shift $(\mathrm{N}=159)$ by using proportional allocation method, $25 \%$ of total number of nurses who are working in surgical units at morning and afternoon shift was selected randomly $(\mathrm{N}=40)$ and included in the study.

Tools: In order to collect the necessary data for the study three main tools were used:

\section{Tool (1): Conditions of Work Effectiveness Questionnaire-II (CWEQ- II)}

It was developed by Laschinger et al. (2001) and revised by Laschinger (2012) The CWEQ-II is a modification of the original Conditions of Work Effectiveness Questionnaire that was developed by Chandler (1986) to measure structural empowerment. It was adopted by the researcher. It consists of 19 items, which measure Kanter's six components of structural empowerment namely; opportunity, information, support, resources, formal power each of this dimension includes (3 items), and informal power (4 items). The responses were measured on a 5-point Likert scale ranging from (1) 'a little' to (5) 'a lot'. A total empowerment score was calculated by summing the CWEQ-II six subscales (range 19-95).

\section{Tool (2): Clinical Nurse Leader Self- Efficacy Scale (CNLSE)}

It was developed by Gilmartin and Nokes (2015). It consists of 35 items designed to assess the nurse's confidence in performance of each of the 9 practice competencies of the clinical nurse leader (CNL) namely: population-based care (9 items), care planning (6 items), unit-based leadership (4 items), managing financial resources (6 items), team management (2 items), continuing education (2 items), mobilizing others (3items), professional leadership (1 items), and mentoring (2 items). The response was measured on a 5-point Likert scale ranging from (1) 'not at all confident' to (5) 'extremely confident'. The overall score level ranging (35-175). 


\section{Tool (3): Clinical Leadership Observation Scale}

It was developed by Kouzes and Posner (2012b) and was adopted by the researcher to assess clinical leadership of staff nurses aligning with Kouzes and Posner (2007). It consists of 30 items measuring leadership five practices namely; challenge the process, establish a shared vision, enable others to act, model the way, and encourage the heart; each dimension composed of (6 items). For purpose of ease response the scale was adapted from ten-point Likert scale to five point Likert scale ranging from "1" almost never to "5" almost always. The overall score range from (30-150).

In addition, a demographic characteristics data sheet was developed by the researcher; and included questions related to gender, age, educational qualification, working unit, years of units and nursing experience

\section{Method:}

- The research plan was submitted to the Research Ethical Committee, Faculty of Nursing, Alexandria University for ethical approval

- An official permission to collect the necessary data for the study was obtained from the Faculty of Nursing, Alexandria University directed to the administrative authorities of Main University Hospital after explanation of the aim of the study .

- Tools (1\& 2) translated into Arabic, and tested for their content validity by five experts in the field of the study.

- Tool (3) clinical leadership observation scale was tested for its validity.

- Tools were tested for their reliability. The internal consistency reliability was assessed using Cronbach's alpha coefficient. Reliability of tool (1) was $=0.81$; too 1 (2) was $=0.77$; tool (3) was $=0.88$. That proved the tools were strongly reliable.

- A pilot study was carried out for $10 \%$ of nurses $(n=4)$ who weren't included in the study subjects, in order to check and ensure the clarity, applicability and feasibility of the tools; identify obstacles and problems and no modification was done.

\section{Data collection}

Study was implemented through the following three phases for 5 months:

\section{Exploratory phase from :( 27-12-2020 to} 26-1-2021)

Data collection was conducted by the researcher pre -program implementation through two methods:

- (a) Self-administered questionnaire namely: Conditions of Work Effectiveness Questionnaire-II (CWEQ-II) tool (1), Clinical Nurse Leader Self-Efficacy Scale (CNLSES) tool (2) that was hand delivered to the study subjects at the study setting to assess nurse's perceptions of structure empowerment and leadership self-efficacy .

- (b)Observation was undertaken by the researcher using tool (3) Clinical Leadership Observation Scale for 40 staff nurses 6 working days per week, 2 hours per day for each nurse (12 hours/week for each nurse) to collect data concerning clinical leadership practices using the observation sheet.

II. Development and implementation of leadership training program: (from $2 / 2$ to 26/2/2021)

\section{- Development of the program}

Based on the result of the exploratory phase and the review of related literature (Kouzes and Posner's, 2005, 2007 and 2012; Hawkins $\&$ Thornton, 2002; Oliver, 2006), the training program was developed, as well as teaching sessions and time schedule.

- Nurses were classified into two groups based on their working days. The program was conducted for 6 working days/ week for six hour per day for each group .The training program had a total of 72 hours training for the two groups.

- The training program was implemented twice one working week for each group and for six hours / day. 


\section{- Implementation of training program}

Before the conduction of training program for nurses, needs assessment questionnaire was distributed to bedside staff nurses to collect data related to their previous training and their needs for leadership development training program.

- A knowledge test (pre- test) was administered to bedside staff nurses to collect data related to their level of knowledge. It consists of questions related to the five leadership practices, as follows: (concept of leadership and leader, the importance of leadership, the principles of leadership, the differences between manager and leader and the element of professional practice) the test was completed in 15 minutes.

- The training program was implemented for bedside staff nurses at the studied hospital, included general and specific objectives, relevant content, educational methods and evaluation technique.

- Content of the program was developed by the researcher based on thorough review of literature (Hawkins \& Thornton, 2002; Kouzes \& Posner, 2005; Kouzes \& Posner, 2012b; Oliver, 2006; Sherman et al., 2007) .

- Also, the five leadership practices: (1) Model the way (Goal setting, Action plan, and Decision making); (2) Inspire a shared vision (vision , mission, and communication skills); (3) Challenging the process (problem solving, innovation, change and risk taking);

(4) Enabling others to act (team building and teamwork, emotional intelligence, coaching and collaboration ); and finally

Encouraging the heart (setting priorities, time management, motivation and creativity)

- The following suitable educational methods was utilized such as: interactive lectures, discussions, brainstorming, case studies, group work and exercise; while computerbased resources (PowerPoint presentations), visual aids (flip charts) and printed materials (handouts) was used as teaching media and instructional resources.

\section{Evaluation of the training program (26/2 to $28 / 4 / 2021)$}

Evaluation of the program was carried out immediately after program implementation using the following steps :

- Participants' reaction questionnaire: the structured form of questionnaire that including questions to measure strong and weak points related to program implementation, such as: objectives, time period, content, time schedule, of the program and teaching strategies.

- The knowledge test (post-test), which was used at the beginning of the program, was applied again to bedside staff nurses at the end of the program; to evaluate the gained knowledge in comparison with the pre-test.

- Self-administrated questionnaire using tools $(1,2)$ of (the Conditions of Work Effectiveness Questionnaire-II, Clinical Nurse Leader Self-Efficacy Scale (CNLSES) that were used in the exploratory phase of the study, were used immediately at the end of the program and after 2 months later from program implementation to reveal the changes in staff nurses' perceptions of structure empowerment and leadership selfefficacy .

- Observation, which undertaken by the researcher using tool (3) clinical leadership observation scale was used immediately at the end of the program and after 2 months later from program implementation to assess changes in staff nurses' behavior regarding leadership practices.

\section{Ethical considerations:}

- Written informed consent from the study subjects were obtained after explaining the aim of the study

- Confidentiality of the data was assured

- Privacy of subjects was maintained

- The subjects' voluntary participation and their right to withdraw from the study at any time was emphasized.

\section{Results}


Table(1) General Demographic characteristics of nurses working in the surgical units illustrates that, mean age of staff nurses was $42.34 \pm 5.371$, the highest percentage $(50 \%)$ of staff nurses had 50 and more years old and less percentage $(15 \%)$ of them in the age group from 30 to less than 40 years old. Regarding of gender the majority (97.5\%) were female. Concerning level of education, $(62.5 \%)$ of staff nurses holding Diploma of Secondary School of Nursing. Pertaining to working unit, the highest percentage $(20.0 \%)$ of staff nurses working in oncology unit compared with low percentage $(7.5 \%)$ of them working in plastic surgery, GIT, colon and rectum units. Regarding to years of experience, the mean score was $20.08 \pm 6.214$ and the majority $(75.0 \%)$ of staff nurses had more than 15 years of experience.

Table (2) Staff nurses' perceptions mean scores of structural empowerment \&its dimensions before, immediately after and after 2months of training program implementation clarifies that, there was a highly statistical significant differences between mean score of overall structure empowerment \& its dimensions in the three phases of evaluation (before, immediately after and after 2 months of training program implementation) where $\mathrm{p}=0.000^{* *}$ and the highest mean scores of overall structural empowerment were found immediately after

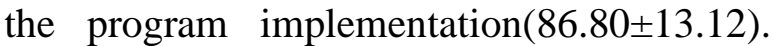
Additionally, a highly statistical significant difference found in all dimensions before, immediately after and after 2months of program implementation where $(\mathrm{p} \leq 0.01)$. The highest mean scores of structural empowerment dimensions was informal power and found immediately after training program implementation (18.25 \pm 3.011$)$.

Table (3) Staff nurses' perception means score of their leadership self-efficacy \& its dimensions before, immediately after and after 2months of training program implementation

exhibits that, there was a highly statistical significant differences between mean score of overall leadership self-efficacy\& its dimensions in the three phases of evaluation (before, immediately after and after 2 months of training program implementation) where $\left(\mathrm{P}=0.000^{* *}\right)$ also, the highest mean score of overall leadership self-efficacy was found immediate after the program implementation $(90.58 \pm 13.34)$.

On another side, there was no statistical significant difference found in mean scores of managing financial resources and continuing education $\quad(10.95 \pm 2.037, \quad 4.030 \pm 0.832)$ respectively. The highest mean score in the dimensions of leadership self-efficacy regarding to population based care was immediately after the program $(23.63 \pm 3.733)$.

Table (4) Staff nurses' mean scores of their clinical leadership practices \& its dimensions before, immediately after and after 2months of training program implementation there was a highly statistical significant difference between mean score of overall clinical leadership practices \& its dimensions in the three phases of evaluation (before, immediately after and after 2month of program implementation) where $\left(\mathrm{P}=0.000^{* *}\right)$. Also, the highest mean score of overall clinical leadership practices was found immediately after program implementation

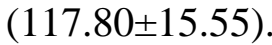

Additionally, a highly statistical significant difference was found in all dimensions before the program, immediately after and after 2 month of program implementation where $\left(\mathrm{P}=0.000^{* *}\right)$ except modeling the way, no statistical significant difference was found between immediately after and after 2 month of program implementation where $(\mathrm{P}=$ 0.354).

\section{Discussion}

Today, due to changing technological and social forces, new leadership responsibilities are placed on the nursing services. This requires staff nurses to be effective leaders who are knowledgeable, skillful and competent in all aspects of leadership (Holes, 2011; McConnell, 2017). The Institute of 
Medicine (2000) report: "to err is human", transformational leadership is identified as the best way to solve leadership problems within healthcare".

\section{Staff nurses' perceptions of structure empowerment, leadership self-efficacy \&clinical leadership practices before, immediately and after 2months of training program implementation}

The findings of the present study proved that there was a highly statistical significant improvements in overall mean scores of structural empowerment and its dimensions before, immediately and after 2 months of the training program implementation, this supported the hypothesis 1 of the study that may be attributed to that, transformational leadership training program provide staff nurses with guidance, information, support to make decisions and solve job problems, believe in their abilities to perform tasks successfully, consider their personality and capability differences, their needs for recognition and approval which lead to increasing their self-esteem and empowerment. This was supported by earlier study of Bryant (2003) who believes that, transformational leadership as an innovative style has been observed as improving nurses' morale and providing an atmosphere of work empowerment. Moreover, Kark et al. (2003) indicated that staff nurses that received training in transformational leadership succeeded in obtaining higher levels of structural empowerment. The result of the study was consistent with Peachy (2002) who reported that there was a significant positive relation between transformational leadership style and the structural empowerment.

This result also reveals that participants perceived a significant increase in overall mean score of leadership self-efficacy\& its dimensions immediately after and after 2 months of the program implementation this supported the hypothesis 2 that may be related to, staff nurses sense of responsibility at their unit in addition to, their abilities and gained skills through doing their best and believing to achieve goals under any condition to fulfill leadership role in addition to their ability to set directions and strengthen their weakness which may lead to promote their leadership performance level and effective achievement of work responsibilities as well as overcoming the difficulties and setbacks also their work experience, more other give them the sense of self-confidence and self-esteem, in turn, affect positively on their perceived selfefficacy. Furthermore, they perceive that skills and knowledge gained in leadership program improved with the increased work experience. Fincher (2008) stated that individual's accomplishments or experiences that decrease self-doubt or reinforce previous positive experiences can give an individual a sense of accomplishment, success and effectiveness.

There was a significant positive improvement after program implementation regarding clinical leadership practices \&its dimensions this supported hypothesis 3; that may be due to the effect of the training program, which expand staff nurses understanding and awareness about the importance of to be future leaders and to have information about clinical leadership practices in enhancing their performance.

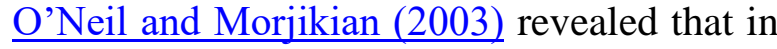
order to respond to the growing challenges facing nursing both from within and from outside the profession, all dimensions of the profession - education, direct care and public health - must develop new ways of organizing and delivering their services and such transitions will require nurses to develop and deploy new clinical leadership skills. Vitaska (2008) concluded that many United States are now mandating leadership assessment "as a lever to improve preparation programs and ongoing professional development and support". This is also supported by Duffield and Franks (2001) who described a lack of formal preparation for the transition and development of clinical nurses into management positions, and that many first-line nurse managers lack appropriate educational qualifications to do their job 
effectively consequently, leadership development are needed.

\section{Conclusion}

The results of the present study concluded that the leadership development training program had positive effect on staff nurses' perceptions of structural empowerment, leadership self-efficacy, and clinical leadership practices. As there were highly significant relations between leadership selfefficacy and structural empowerment, also between clinical leadership practices and structural empowerment and between clinical leadership practices and leadership selfefficacy immediately after program implementation

\section{Recommendations}

Based on the findings of the present study, more efforts still needed to promote leadership development.The hospital

\section{administrator should:}

- Establish and organize training programs for staff nurses related to recent strategies of problem solving and critical thinking. These training programs can be conducted either inside the hospital or outside through a coordination with faculty of nursing.

- Overcome any obstacles and problems that may face them during continuing their education as high financial cost and lack of coordination between work time and educational time

- Provide solutions for the dramatic nursing shortage in the hospital through fair distribution of nurses between hospitals and health care centers and the claim for increasing number of nursing staff. 
Table (1): General demographic characteristics of staff nurses working in the surgical units

\begin{tabular}{|c|c|c|c|}
\hline \multirow{2}{*}{\multicolumn{2}{|c|}{ Demographic data }} & \multicolumn{2}{|c|}{ Total $(n=40)$} \\
\hline & & \multirow{2}{*}{\begin{tabular}{|l|} 
No. \\
7 \\
\end{tabular}} & \multirow{2}{*}{$\begin{array}{l}\% \\
17.5 \\
\end{array}$} \\
\hline \multirow[t]{5}{*}{ Age (years) } & 20- & & \\
\hline & 30- & 6 & 15.0 \\
\hline & 40- & 7 & $\mathbf{1 7 . 5}$ \\
\hline & $\geq \mathbf{5 0}$ & 20 & 50.0 \\
\hline & $($ Mean \pm SD $)$ & \multicolumn{2}{|c|}{$42.34 \pm 5.371$} \\
\hline \multirow[t]{2}{*}{ Sex } & Male & 1 & 2.5 \\
\hline & Female & 39 & 97.5 \\
\hline \multirow[t]{2}{*}{ Level of education } & Technical Institute of Nursing & 15 & 37.5 \\
\hline & Diploma of Secondary School of Nursing & 25 & 62.5 \\
\hline \multirow[t]{8}{*}{ Working unit } & Cardio thorax & 6 & 15.0 \\
\hline & Vascular & 7 & $\mathbf{1 7 . 5}$ \\
\hline & Neurosurgery & 5 & 12.5 \\
\hline & Plastic & 3 & 7.5 \\
\hline & GIT & 3 & 7.5 \\
\hline & Colon and rectum & 3 & 7.5 \\
\hline & Oncology & 8 & 20.0 \\
\hline & Children urology & 5 & 12.5 \\
\hline \multirow[t]{5}{*}{ Years of experience } & $<5$ & 3 & 7.5 \\
\hline & 5- & 4 & $\mathbf{1 0 . 0}$ \\
\hline & 10- & 3 & 7.5 \\
\hline & $\geq 15$ & 30 & 75.0 \\
\hline & $($ Mean \pm SD $)$ & \multicolumn{2}{|c|}{$20.08 \pm 6.214$} \\
\hline \multirow[t]{2}{*}{ Working shift } & Morning & 20 & 50.0 \\
\hline & Evening & 20 & 50.0 \\
\hline
\end{tabular}

Table (2): Staff nurses' perceptions mean score of structural empowerment before, immediately after and after 2 months of training program implementation

\begin{tabular}{|c|c|c|c|c|}
\hline \multirow[t]{3}{*}{ Items } & \multicolumn{3}{|l|}{ Total $(n=40)$} & \multirow{3}{*}{ Test of Significance } \\
\hline & Before & Post 1 & Post 2 & \\
\hline & Mean \pm SD & Mean \pm SD & Mean \pm SD & \\
\hline \multicolumn{5}{|l|}{ Opportunity } \\
\hline \multirow[t]{2}{*}{ Mean \pm SD } & $10.43 \pm 2.406$ & $14.08 \pm 2.153$ & $11.70 \pm 2.312$ & \multirow{2}{*}{$\begin{array}{l}\mathrm{t}^{\mathrm{a}}=51.12 \mathrm{P}=0.000^{*} \\
\mathrm{t}^{\mathrm{b}}=\mathbf{5 . 8 4 1} \mathrm{P}=0.018 * \\
\mathrm{t}^{\mathrm{c}}=\mathbf{2 2 . 6 1} \mathrm{P}=\mathbf{0 . 0 0 0} *\end{array}$} \\
\hline & \multicolumn{3}{|c|}{$F=26.115 P=0.000^{*}$} & \\
\hline \multicolumn{5}{|l|}{ Information } \\
\hline \multirow[t]{2}{*}{ Mean \pm SD } & $8.500 \pm 2.298$ & $13.98 \pm 2.315$ & $11.53 \pm 1.867$ & \multirow{2}{*}{$\begin{array}{l}\mathbf{t}^{\mathrm{a}}=112.68 \mathrm{P}=0.000^{*} \\
\mathrm{t}^{\mathrm{b}}=41.74 \mathrm{P}=\mathbf{0 . 0 0 0} * \\
\mathrm{t}^{\mathrm{c}}=\mathbf{2 7 . 1 4} \mathrm{P}=\mathbf{0 . 0 0 0} *\end{array}$} \\
\hline & \multicolumn{3}{|c|}{$\mathrm{F}=63.890 \mathrm{P}=0.000 *$} & \\
\hline \multicolumn{5}{|l|}{ Support } \\
\hline \multirow[t]{2}{*}{ Mean \pm SD } & $10.03 \pm 2.851$ & $13.70 \pm 2.053$ & $12.25 \pm 2.468$ & \multirow{2}{*}{$\begin{array}{l}\mathrm{t}^{\mathrm{a}}=43.77 \mathrm{P}=0.000^{*} \\
\mathrm{t}^{\mathrm{b}}=13.93 \mathrm{P}=0.000^{*} \\
\mathrm{t}^{\mathrm{c}}=\mathbf{8 . 1 6 1} \mathrm{P}=\mathbf{0 . 0 0 5}^{*}\end{array}$} \\
\hline & \multicolumn{3}{|c|}{$F=22.307 \quad P=0.000 *$} & \\
\hline \multicolumn{5}{|l|}{ Resources } \\
\hline \multirow[t]{2}{*}{ Mean \pm SD } & $9.680 \pm 2.347$ & $14.05 \pm 2.012$ & $12.05 \pm 2.364$ & \multirow{2}{*}{$\begin{array}{l}\mathrm{t}^{\mathrm{a}}=\mathbf{8 0 . 1 2} \mathrm{P}=0.000^{*} \\
\mathrm{t}^{\mathrm{b}}=\mathbf{2 0 . 3 4} \mathrm{P}=\mathbf{0 . 0 0 0} * \\
\mathrm{t}^{\mathrm{c}}=\mathbf{1 6 . 6 1} \mathrm{P}=\mathbf{0 . 0 0 0} *\end{array}$} \\
\hline & \multicolumn{3}{|c|}{$F=38.013 P=0.000 *$} & \\
\hline \multicolumn{5}{|c|}{ Formal power } \\
\hline \multirow[t]{2}{*}{ Mean \pm SD } & $8.730 \pm 2.407$ & $12.75 \pm 2.239$ & $10.07 \pm 2.505$ & \multirow{2}{*}{$\begin{array}{l}\mathbf{t}^{\mathrm{a}}=59.96 \mathrm{P}=0.000^{*} \\
\mathrm{t}^{\mathrm{b}}=\mathbf{6 . 0 4 0} \mathrm{P}=\mathbf{0 . 0 1 6} * \\
\mathrm{t}^{\mathrm{c}}=\mathbf{2 5 . 3 5} \mathrm{P}=0.000^{*}\end{array}$} \\
\hline & $F=29.478 P$ & & & \\
\hline \multicolumn{5}{|c|}{ Informal power } \\
\hline \multirow[t]{2}{*}{ Mean \pm SD } & $13.15 \pm 3.101$ & $18.25 \pm 3.011$ & $17.13 \pm 2.564$ & \multirow{2}{*}{$\begin{array}{l}\mathbf{t}^{\mathrm{a}}=55.69 \mathrm{P}=\mathbf{0 . 0 0 0} * \\
\mathrm{t}^{\mathrm{b}}=39.03 \mathrm{P}=\mathbf{0 . 0 0 0} * \\
\mathbf{t}^{\mathrm{c}}=3.237 \mathrm{P}=\mathbf{0 . 0 7 6}\end{array}$} \\
\hline & \multicolumn{3}{|c|}{$F=34.112 P=0.000 *$} & \\
\hline \multicolumn{5}{|c|}{ Total perception of structure empowerment } \\
\hline Mean \pm SD & $60.50 \pm 11.47$ & $86.80 \pm 13.12$ & $74.73 \pm 10.61$ & $\begin{array}{l}\mathbf{t}^{\mathrm{a}}=91.15 \mathrm{P}=0.000 * \\
\mathbf{t}^{\mathrm{b}}=33.18 \mathrm{P}=\mathbf{0 . 0 0 0} * \\
\mathbf{t}^{\mathrm{c}}=\mathbf{2 0 . 4 9} \mathrm{P}=\mathbf{0 . 0 0 0} *\end{array}$ \\
\hline
\end{tabular}


Table (3): Staff nurses' perceptions mean scores of their leadership self-efficacy before, immediately after and after 2 months of training program implementation

\begin{tabular}{|c|c|c|c|c|}
\hline \multirow{3}{*}{ Items } & \multicolumn{3}{|l|}{ Total $(n=40)$} & \multirow{3}{*}{ Test of Significance } \\
\hline & Before & Post 1 & Post 2 & \\
\hline & Mean \pm SD & $\begin{array}{l}{ }_{ \pm \text {SD }}^{\text {Mean }} \\
\end{array}$ & ${ }_{ \pm \text {SD }}^{\text {Mean }}$ & \\
\hline \multicolumn{5}{|c|}{ Population based care } \\
\hline \multirow[t]{2}{*}{ Mean \pm SD } & $19.03 \pm 7.399$ & $\operatorname{3.733}^{23.63 \pm}$ & $\begin{array}{ll} & 16.85 \pm 2.6 \\
75 & \end{array}$ & \multirow{2}{*}{$\begin{array}{l}t^{\mathrm{a}}=12.33 \mathrm{P}=0.001 \\
\mathrm{t}^{\mathrm{b}}=3.057 \mathrm{P}=0.084 \\
\mathrm{t}^{\mathrm{c}}=\mathbf{8 7 . 0 6 \mathrm { P }}=\mathbf{0 . 0 0 0 ^ { * }}\end{array}$} \\
\hline & \multicolumn{3}{|c|}{$F=18.934 P=0.000^{*}$} & \\
\hline \multicolumn{5}{|c|}{ Care Planning } \\
\hline \multirow{2}{*}{ Mean \pm SD } & $14.25 \pm 5.453$ & $3.004^{17.00 \pm}$ & $\begin{array}{ll} & 13.40 \pm 4.6\end{array}$ & \multirow{2}{*}{$\begin{array}{l}t^{\mathrm{a}}=7.805 \mathrm{P}=0.007 \\
\mathrm{t}^{\mathrm{b}}=0.563 \mathrm{P}=0.455 \\
\mathrm{t}^{\mathrm{c}}=16.91 \mathrm{P}=0.000^{*}\end{array}$} \\
\hline & \multicolumn{3}{|c|}{$\mathrm{F}=7.036 \mathrm{P}=0.001 *$} & \\
\hline \multicolumn{5}{|c|}{ Unit based leadership } \\
\hline \multirow[t]{2}{*}{ Mean \pm SD } & $8.400 \pm 3.593$ & $a_{1.881}^{13.48 \pm}$ & $94 \quad 12.15 \pm 1.9$ & \multirow{2}{*}{$\begin{array}{l}t^{\mathrm{a}}=62.63 \mathrm{P}=0.000^{*} \\
\mathrm{t}^{\mathrm{b}}=33.30 \mathrm{P}=0.000^{*} \\
\mathrm{t}^{\mathrm{c}}=9.345 \mathrm{P}=0.003^{*}\end{array}$} \\
\hline & \multicolumn{3}{|c|}{$\mathrm{F}=40.704 \mathrm{P}=0.000 *$} & \\
\hline \multicolumn{5}{|c|}{ Managing financial resources } \\
\hline \multirow[t]{2}{*}{ Mean \pm SD } & $12.40 \pm 5.481$ & $2.037^{10.95 \pm}$ & 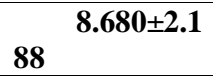 & \multirow{2}{*}{$\begin{array}{l}\mathrm{t}^{\mathrm{a}}=2.460 \mathrm{P}=0.121 \\
\mathrm{t}^{\mathrm{b}}=15.94 \mathrm{P}=0.000 * \\
\mathrm{t}^{\mathrm{c}}=\mathbf{2 . 1 5 6} \mathrm{P}=\mathbf{0 . 0 0 0} *\end{array}$} \\
\hline & \multicolumn{3}{|c|}{$\mathrm{F}=10.853 \mathrm{P}=0.000^{*}$} & \\
\hline \multicolumn{5}{|c|}{ Team management } \\
\hline \multirow{2}{*}{ Mean \pm SD } & $4.150 \pm 2.045$ & $1.317^{6.400 \pm}$ & $91 \quad 4.850 \pm 1.7$ & \multirow{2}{*}{$\begin{array}{l}\mathbf{t}^{\mathrm{a}}=34.23 \mathrm{P}=0.000^{*} \\
\mathrm{t}^{\mathrm{b}}=\mathbf{2 . 6 5 2} \mathrm{P}=\mathbf{0 . 1 0 7} \\
\mathrm{t}^{\mathrm{c}}=\mathbf{1 9 . 4 5} \mathrm{P}=\mathbf{0 . 0 0 0 ^ { * }}\end{array}$} \\
\hline & $\mathrm{F}=17.439 \mathrm{P}$ & & & \\
\hline \multicolumn{5}{|c|}{ Continuing education } \\
\hline \multirow[t]{2}{*}{ Mean \pm SD } & $4.480 \pm 2.298$ & $0.832^{4.030 \pm}$ & $42 \quad 3.650 \pm 1.6$ & \multirow{2}{*}{$\begin{array}{l}t^{a}=1.356 P=0.248 \\
t^{b}=3.413 P=0.068 \\
t^{c}=1.661 P=0.201\end{array}$} \\
\hline & $\mathrm{F}=2.362 \mathrm{P}=$ & & & \\
\hline \multicolumn{5}{|c|}{ Mobilizing others } \\
\hline \multirow{2}{*}{ Mean \pm SD } & $5.850 \pm 2.896$ & ${ }_{1.440}^{9.930 \pm}$ & $\begin{array}{ll} & 9.930 \pm 0.8 \\
88 & \end{array}$ & \multirow{2}{*}{$\begin{array}{l}t^{a}=7.978 P=0.000 * \\
t^{b}=7.978 P=0.000 * \\
t^{c}=-\cdots--P=\cdots\end{array}$} \\
\hline & $\mathrm{F}=10.827 \mathrm{P}=$ & & & \\
\hline \multicolumn{5}{|c|}{ Professional leadership } \\
\hline \multirow[t]{2}{*}{ Mean \pm SD } & $2.000 \pm 1.086$ & $e^{2.764}{ }^{2.680 \pm}$ & \begin{tabular}{|l} 
\\
54
\end{tabular} & $\begin{array}{l}\mathrm{t}^{\mathrm{a}}=10.34 \mathrm{P}=0.002^{*} \\
\mathrm{t}^{\mathrm{b}}=1.196 \mathrm{P}=0.277\end{array}$ \\
\hline & $\mathrm{F}=5.227 \mathrm{P}=$ & & & \\
\hline Mentoring & & & & \\
\hline Mean \pm SD & $4.000 \pm 2.124$ & $1.301^{7.500 \pm}$ & 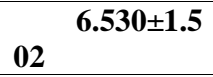 & $\begin{array}{l}\mathrm{t}^{\mathrm{a}}=\text { 78.97 } \mathrm{P}=0.000^{*} \\
\mathrm{t}^{\mathrm{b}}=37.68 \mathrm{P}=0.000^{*}\end{array}$ \\
\hline & $F=46.275 P=$ & & & $\mathrm{t}^{\mathrm{c}}=9.631 \mathrm{P}=0.003^{*}$ \\
\hline Total Lead & & & & \\
\hline Mean \pm SD & $73.67 \pm 27.98$ & ${ }_{13.34}^{90.58 \pm}$ & $\begin{array}{ll} & 82.28 \pm 10 . \\
93 & \end{array}$ & $\begin{array}{l}\mathrm{t}^{\mathrm{a}}=11.89 \mathrm{P}=0.001^{*} \\
\mathrm{t}^{\mathrm{b}}=1.813 \mathrm{P}=0.074\end{array}$ \\
\hline & $\mathrm{F}=11.525 \mathrm{P}=$ & & & $\mathrm{t}^{\mathrm{c}}=3.044 \mathrm{P}=0.003^{*}$ \\
\hline
\end{tabular}


Table (4): Staff nurses' mean scores of their clinical leadership practices before, immediately after and after 2months of training program implementation

\begin{tabular}{|c|c|c|c|c|}
\hline \multirow{3}{*}{ Items } & \multicolumn{3}{|l|}{ Total $(n=40)$} & \multirow{3}{*}{ Test of Significance } \\
\hline & Before & Post 1 & Post 2 & \\
\hline & Mean \pm SD & Mean \pm SD & Mean \pm SD & \\
\hline \multicolumn{5}{|c|}{ Challenge the process } \\
\hline \multirow[t]{2}{*}{ Mean \pm SD } & $9.470 \pm 3.974$ & $24.25 \pm 4.186$ & $\begin{array}{l}16.80 \pm 5.09 \\
0\end{array}$ & 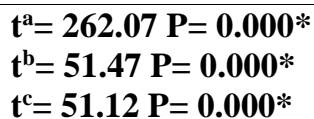 \\
\hline & \multicolumn{3}{|c|}{$\mathrm{F}=110.57 \mathrm{P}=0.000^{*}$} & \\
\hline \multicolumn{5}{|c|}{ Establish a shared vision } \\
\hline \multirow[t]{2}{*}{ Mean \pm SD } & $9.200 \pm 4.381$ & $18.35 \pm 3.438$ & $\begin{array}{l}13.55 \pm 3.38 \\
9\end{array}$ & 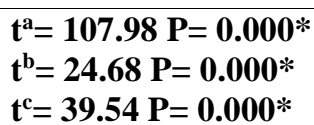 \\
\hline & \multicolumn{3}{|c|}{$\mathrm{F}=59.149 \mathrm{P}=0.000 *$} & \\
\hline \multicolumn{5}{|c|}{ Enable others to act } \\
\hline \multirow[t]{2}{*}{ Mean \pm SD } & $16.45 \pm 4.585$ & $27.78 \pm 3.347$ & $\begin{array}{l}24.13 \pm 4.82 \\
6\end{array}$ & $\begin{array}{l}\mathrm{t}^{\mathrm{a}}=159.19 \mathrm{P}=0.000 * \\
\mathrm{t}^{\mathrm{b}}=\mathbf{5 3 . 1 7} \mathrm{P}=0.000 * \\
\mathrm{t}^{\mathrm{c}}=15.45 \mathrm{P}=0.000 *\end{array}$ \\
\hline & \multicolumn{3}{|c|}{$\mathrm{F}=72.221 \mathrm{P}=0.000^{*}$} & \\
\hline \multicolumn{5}{|c|}{ Model the way } \\
\hline \multirow[t]{2}{*}{ Mean \pm SD } & $10.03 \pm 3.745$ & $22.38 \pm 3.052$ & $\begin{array}{l}21.60 \pm 4.28 \\
4\end{array}$ & $\begin{array}{l}\mathrm{t}^{\mathrm{a}}=261.37 \mathrm{P}=0.000 * \\
\mathrm{t}^{\mathrm{b}}=165.54 \mathrm{P}=0.000 \\
\mathrm{t}^{\mathrm{c}}=0.868 \mathrm{P}=0.354\end{array}$ \\
\hline & \multicolumn{3}{|c|}{$\mathrm{F}=137.729 \mathrm{P}=0.000^{*}$} & \\
\hline \multicolumn{5}{|c|}{ Encourage the heart } \\
\hline \multirow[t]{2}{*}{ Mean \pm SD } & $11.50 \pm 4.385$ & $25.05 \pm 3.404$ & $\begin{array}{l}21.60 \pm 5.06 \\
3\end{array}$ & $\begin{array}{l}\mathrm{t}^{\mathrm{a}}=238.31 \mathrm{P}=0.000 * \\
\mathrm{t}^{\mathrm{b}}=\mathbf{9 0 . 9 6} \mathrm{P}=0.000 * \\
\mathrm{t}^{\mathrm{c}}=12.79 \mathrm{P}=0.001 *\end{array}$ \\
\hline & \multicolumn{3}{|c|}{$\mathrm{F}=105.411 \mathrm{P}=0.000^{*}$} & \\
\hline \multicolumn{5}{|c|}{ Total Clinical Leadership Practices } \\
\hline \multirow[t]{2}{*}{ Mean \pm SD } & $56.65 \pm 16.11$ & $\begin{array}{l}117.80 \pm 15.5 \\
5\end{array}$ & $\begin{array}{l}97.68 \pm 19.3 \\
5\end{array}$ & $\begin{array}{l}\mathrm{t}^{\mathrm{a}}=298.24 \mathrm{P}=0.000 * \\
\mathrm{t}^{\mathrm{b}}=\mathbf{1 0 6 . 1 5} \mathrm{P}=0.000 * \\
\mathrm{t}^{\mathrm{c}}=\mathbf{2 6 . 2 8} \mathrm{P}=\mathbf{0 . 0 0 0} *\end{array}$ \\
\hline & \multicolumn{3}{|c|}{$F=133.037 P=0.000 *$} & \\
\hline
\end{tabular}




\section{References}

- Bryant, S. E. (2003). The Role of Transformational and Transactional Leadership in Creating, Sharing and Exploiting Organizational Knowledge.Journal of Leadership \& Organizational Studies, 9(4), 32-44.

- Carlson-Catalano, J. (1992). Empowering nurses for professional practice. Nursing outlook, 40(3), 139142.

- Chandler, G. E. (1986). The relationship of nursing work environment to empowerment and powerlessness $[\mathrm{PhD}$ Thesis]. University of Utah.

- Chávez, E. C., \& Yoder, L. H. (2015). Staff nurse clinical leadership: a concept analysis. Nursing forum,50(2),90-100.

- Clark, C. (2011). Creative nursing leadership and management ( $6^{\text {th }}$ ed.). Jones and Bartlett publisher.

- Duffield, C., \& Franks, H. (2001). The role and preparation of first-line nurse managers in Australia: where are we going and how do we get there? Journal of nursing management, 9(2), 87-91.

- Echebiri, C., Amundsen, S., \& Engen, M. (2020). Linking Structural Empowerment to Employee-Driven Innovation: The Mediating Role of Psychological Empowerment. Administrative Sciences, 10(3), 42.

- Evans, M. (2016). Developing the role of leader. In P. Yoder-Wise, L. Grant \& S. Regan (Eds.), Leading and Managing in Canadian Nursing (p.p. 36-53). Elsevier.

- Feltner, A., Mitchell, B., Norris, E., \& Wolfle, C. (2008). Nurses' views on the characteristics of an effective leader. AORN journal, 87(2), 363-372.

- Fincher, J. (2008). Leadership selfefficacy for college students with learningdisability [Master Thesis]. Maryland University.

- Gilmartin, M. J., \& Nokes, K. (2015). A Self-Efficacy Scale for Clinical Nurse Leaders: Results of a Pilot Study. Nursing economic\$, 33(3), 133-143.
- Hannah, S. T., Avolio, B. J., Luthans, F., \& Harms, P. D. (2008). Leadership efficacy: Review and future directions. The Leadership Quarterly,19(6),669692.

- Hawkins, E., \& Thornton, C. (2002). Six Steps to Effective Management: Managing and Leading Innovation in Health Care. Balliere Tindall.

- Holes, A. (2011). Nursing leadership. Nursing Management 42(4), 34-38.

- Institute of Medicine. (2000). To Err is Human: Building a safe health system. Institute of Medicine.

- Kanter, R. M. (1993). Men and Women of the Corporation. Basic Books.

- Kark, R., Shamir, B., \& Chen, G. (2003). The two faces of transformational leadership: empowerment and dependency. The Journal of applied psychology, 88(2), 246-255.

- Kouzes, J. M., \& Posner, B. Z. (2007). The Leadership Challenge: How to Make Extraordinary Things Happen in Organizations ( $4^{\text {th }}$ ed.). Jossey-Bass.

- Kouzes, J. M., \& Posner, B. Z. (2012b). The leadership challenge: How to make extraordinary things happen in organizations. Josey-Bass.

- Laschinger, H. K. (2012). Conditions for Work Effectiveness Questionnaire I and II. Published instrument. http://www.uwo.ca/fhs/hkl/cweq.html

- Laschinger, H. K., Finegan, J., Shamian, J., \& Wilk, P. (2001). Impact of structural and psychological empowerment on job strain in nursing work settings: expanding Kanter's model. The Journal of nursing administration, 31(5), 260-272.

- Laschinger, H. K., Purdy, N., \& Almost, J. (2007). The impact of leader-member exchange quality, empowerment, and core self-evaluation on nurse manager's job satisfaction. The Journal of nursing administration, 37(5), 221-229. 
- McConnell, C. R. (2017). Accepting Leadership Responsibility: Preparing Yourself to Lead Honestly, Humanely, and Effectively. The health care manager, 36(3), 247-260.

- O'Neil, E., \& Morjikian, R. (2003). Nursing leadership: Challenges and opportunities. Policy, Politics, \& Nursing Practice, 4(3), 173-179.

- Oliver, S. (2006). Leadership in health care. Musculoskeletal care, 4(1), 38-47.

- Paglis, L. L. (2010). Leadership self-efficacy: research findings and practical applications. Journal of Management Development, 29(9), 771782.

- Paglis, L. L., \& Green, S. G. (2002). Leadership self-efficacy and managers' motivation for leading change. Journal of Organizational Behavior, 23(2), 215235.

- Patrick, A., Laschinger, H. K., Wong, C., \& Finegan, J. (2011). Developing and testing a new measure of staff nurse clinical leadership: the clinical leadership survey. Journal of nursing management, 19(4), 449-460.

- Peachy, G. (2002). The effect of transformational leadership behaviors on staff nurses workplace empowerment, psychological empowerment, organizational commitment and absenteeism [PhD Thesis]. Mc-Master University.

- Sherman, R. O., Bishop, M., Eggenberger, T., \& Karden, R. (2007). Development of a leadership competency model. The Journal of nursing administration, 37(2), 85-94.

- Tjosvold, D., \& Wong, A. S. H. (2000). The leader relationship: building teamwork with and among employees. Leadership \& Organization Development Journal, 21(7), 350-354. https://doi.org/10.1108/0143773001037 7890 .

- Vitaska, S. (2008). Strong leaders strong schools 2007 state laws. National Conference of State Legislatures. 